Иван Бобров, Дмитрий Михайлов

\title{
«ВНУТРЕННИЕ ВРАГИ» СОВРЕМЕННОГО РУССКОГО НАЦИОНАЛИЗМА
}

Третий президентский срок Владимира Путина характеризуется включением повестки национальной безопасности в контекст социальной политики. В связи с этим в ретрансляторах идеологии власти все активнее задействуются идеологемы современных русских националистов, среди которых центральное место занимает образ «внутреннего врага». Статья посвящена особенностям его формирования, как одной из ключевых идеологических составляющих процесса идентификации современного русского национализма. В связи с тем, что категории анализа, описывающие фрагментированное поле современного русского национализма способны ввести в заблуждение, мы используем в своей работе термин «русские националисты» как категорию политической практики. Принимаются во внимание те общественные деятели, которые сами себя называют русскими националистами. В рассматриваемом интеллектуальном пространстве прослеживаются три риторических стратегии, формирующие образ внутреннего врага: историческая, теоретическая и этническая. Первая сводится к идее о том, что национальным меньшинствам принадлежит ключевая роль в уничтожении Российской Империи. Вторая риторическая линия выражается в атаке на современные официальные формулировки единства российской нации. Формирование образа внутреннего врага русским национализмом во многом является реакцией на поликультурную идеологию современной России. Речь идет о ключевых документах, определяющих государственную национальную политику,-

Иван Владимирович Бобров - студент 4 курса факультета политики и международных отношений, Сибирский институт управления филиала Российской академии народного хозяйства и государственной службы при Президенте РФ, Новосибирск, Россия. Электронная почта: ivan.v.bobrov@gmail.com

Дмитрий Алексеевич Михайлов - к. и. н., доцент, Сибирский институт управления филиала Российской академии народного хозяйства и государственной службы при Президенте РФ, Новосибирск, Россия. Электронная почта: damihan@yandex.ru 
Конституцию и Концепцию государственной национальной политики, которая была обновлена в 2012 г. Наконец, третья, наиболее агрессивная риторическая линия в формировании образа внутреннего врага обращена на дискредитацию конкретных этнических сообществ. В содержательных характеристиках внутреннего врага русского народа националисты отводят центральное место представителям Кавказа.

Ключевые слова: русский национализм, научный национализм, внутренний враг, новиоп

DOI: $10.17323 / 727-0634-2018-16-2-279-294$

Конструирование образа врага посредством выведения части политического спектра за рамки национального сообееста можно рассматривать как универсальный механизм, который сопровождает процесс национального самоопределения с его зарождения. Риторика предательства актуализируется с момента суверенизации нации, когда происходит нивелирование сословных различий внутри вертикальных донововоременных сообществ. Механизмы формирования образа врага входят в повседневные практики современных политий, однако их актуализация возрастает в кризисные моменты. В этом отношении особый интерес представляет последовавшая после выборов 2011 и 2012 гг. трансформация системы отношений между российской властью и обществом, результатом которой стало переопределение ключевых политических акторов (Gelman 2015: 17). На смену административной, апеллирующей к экономической целесообразности стратегии, пришла стратегия секьюритизации ключевых сфер общественной жизни (Makarychev, Yatsyk 2014: 2). Под последней понимается комплекс практик, направленных на формирование у объекта чувства критической уязвимости, следствием чего становится появление потребности в немедленном устранении угрозы путем использования чрезвычайных мер (Якушина 2012).

Эта стратегия сама по себе подразумевает переопределение границ политии, т.е. превращение оппозиционного, протестующего спектра во внутренних врагов. При этом речь идет не о политиках, а о категориях населения и определенном образе жизни, что нашло отражение в нормативной базе. Так, начиная с 2012 г. секьюритизации подвергались различные проявления общественной жизни: религиозные чувства, некоммерческие организации, публичные общественные мероприятия, гомосексуальные отношения (Lipman 2015: 232).

В связи с этим в публичной риторике все заметнее проявляется концептуальный арсенал русских националистов. Национальный дискурс стал ключевым в трактовке событий в Украине (Kolstø, Blakkisrud 2016: 1-18), нечто названное «технологией майдана» представлялось как деятельность внутренних врагов. Для этого оказались востребованы 
не только идеологемы русских националистов, но и наиболее яркие их представители, которые вошли в официальное медийное пространство. В частности, в 2013-2016 гг. газета «Известия» превратилась в площадку консервативно настроенных российских интеллектуалов. Статья посвящена особенностям формирования образа внутреннего врага, как одной из ключевых идеологических составляющих процесса идентификации современного русского национализма.

\section{Современные русские националисты}

Поскольку категории анализа, описывающие фрагментированное поле современного русского национализма способны ввести в заблуждение, мы используем термин «русские националисты» как понятие политической практики (Brubaker, Cooper 2000:3-5). Нами будут приниматься во внимание те общественные деятели, которые сами себя называют русскими националистами. И это не формальный подход к вопросу, поскольку сам факт обозначения себя «националистом» в российском дискурсивном пространстве, в силу сложившейся традиции противопоставления национализма и патриотизма, имеет сильное смысловое значение. Отличительной чертой русского национализма советского периода был традиционализм в форме неопочвенничества с характерными ему недоверием к Западу, антисемитизмом, идеями «особого пути» и возрождения крестьянства (Митрохин 2003: 562; Партэ 2004: 13-20). В период идеологического коллапса начала 1990-х гг. в противовес русофильскому традиционализму складывается идеология русского национализма, апеллирующая к западным ценностям - индивидуализму и демократии.

В 1994 г. философ Сергей Чернышов организовал издание хрестоматии «Иное», определив ее как «философский пароход, который возвращается на родину» (Чернышов 1995). В нее вошла статья писателя и философа Дмитрия Галковского «Русская политика и русская философия», в которой «европейский» вариант русского национализма получил концептуальное обоснование. Галковский осмысляет Россию в контексте дихотомии «Восток - Запад»: ключевым качеством «европейскости» он считает уважение к личности, которое противостоит коллективистской «азиатчине», характерной не только для русского крестьянства, но и для интеллигенции (Галковский 1994). Идеи Галковского получили развитие в гостевой книге его интернетресурса «Самиздат», функционировавшего в конце 1990-х гг. Среди пользователей сайта выделяются известные деятели националистического направления, основатели ресурса Doctrina.ru, публицисты Агентства политических новостей Константин Крылов, Егор Холмогоров и Наталья Холмогорова.

Институциально «европейский» вариант русского национализма оформляется в форме национал-демократического движения в середине 2000-х гг. (Pain 2016:53-54). В программе незарегистрированной «Нацио- 
нально-демократической партии», лидером которой является Константин Крылов, утверждается, что «Россия является страной с европейской идентичностью», и ставится задача «построить государство европейского типа» (Национально-демократическая партия 2012). Аналогичные идеи отстаивает журнал академического формата «Вопросы национализма». По замыслу редакции он призван стать «теоретическим органом русских националистов, прежде всего, русского национального освободительного движения или национал-демократов» (Крылов 2010с).

Позднее в блоге на платформе Живого Журнала Галковский сформулирует идею криптоколонии - скрытого господства Запада и обслуживающих его колониальную политику «новиопов» - национальных меньшинств. В построениях Галковского внутренний враг концептуально связан с врагом внешним: Британия стала использовать национальные меньшинства России для обеспечения своего господства над русским народом. На этом уровне рассуждений проблема международных отношений, переводится Галковским во внутренний контекст: субъекты внутренней политики характеризуются им в ярко выраженной ориенталистской терминологии, приобретая при этом этническую окраску. Общество, сформировавшееся в современной России, по Галковскому, состоит из двух народов: русскому - «европейцу» противостоят новиопы - «азиаты» (новиопы от «новая историческая общность»), это «не русские» (Галковский 2009). Внутренний враг русского народа представляется Галковским как этническая группа, которая состоит «из средних и низших слоёв общества и из народов-зародышей и народов-обрезков» (Галковский 2012). При этом само сочетание культурных элементов в ней непринципиально, поскольку главный ее смысл в «нерусскости»: «никакой разницы между чеченцем, евреем или киргизом нет. Этот режим их, а суть этого режима как раз и исчерпывается тем, что он Нероссия» (там же).

Ценности «европейского» национализма лежат и в основе идеологии «Спутника и Погрома» - самого популярного проекта (более миллиона посетителей в месяц) русских националистов в интернете, который

видит своей стратегической задачей воспитание русской национальной элиты для русского национального государства и пытается привить ценности русского демократического дореволюционного национализма (Спутник и Погром 2014c).

Рассматриваемый круг русских националистов играет значительную роль в формировании общественного мнения. В ходе опроса, проведенного интернет-журналом Colta.ru в 2013 г., Крылов и Галковский заняли 9 и 21 места соответственно, а националист Просвирнин занял второе место, уступив лишь Алексею Навальному (Colta.ru 2013). Анализ публицистики представителей современного русского национализма позволяет выделить три риторических стратегии, формирующих образ внутреннего врага: историческую, теоретическую и этническую. 


\section{Актуальное прошлое}

Центральное место в обсуждении националистами прошлого занимают события 1917 г. Формирование образа внутреннего врага выражается в утверждении идеи, что национальные меньшинства - создатели современного антирусского политического режима, который является преемником советского государства. Советское государство понимается современными националистами как принципиально антирусское. Эффект исторической реальности поддерживается конспирологическими построениями, в которых ключевую роль играет колониальная риторика. При этом речь идет не только о популярной версии измены большевиков в пользу Германии. В этом историческом нарративе ключевая роль в уничтожении Российской империи принадлежит национальным меньшинствам. Александр Севастьянов пишет:

Революция и Гражданская война со стороны красных по своим целям и задачам была антирусской, по своему исходному замыслу и по руководству еврейской, по своим движущим силам в значительной, если не определяющей, степени нерусской (Севастьянов 2009).

С его точки зрения, в переломные моменты гражданской войны на помощь большевикам приходили нерусские силы (Севастьянов 2012а). Эту же позицию отстаивает публицист Александр Самолетов, который утверждает, что красная армия состояла более чем на половину из нерусских: «Одних латышских стрелков было столько, сколько у Деникина всех боеспособных бойцов во время начала его похода на Москву» (Самоваров 2013).

Любопытно, что при этом истоки проблемы подчиненности русского населения «инородцам» выводятся из дооктябрьского периода, что позволяет националистам задействовать риторику «внутреннего колониализма». В частности, публицист Сергей Сергеев, ссылаясь на идеи русского консерватора второй половины XIX в. Михаила Каткова о национальном государстве, пишет:

Между тем, в России господствует система, направленная на то, чтобы выделить инородческие населения, поддерживать и развивать правительственными способами чуждые русской народности элементы, встречающиеся на ее громадной территории, и, наконец, в этой искусственной отдельности возвышать их над русской народностью (Сергеев 2012).

Все историческое пространство России националистами гомогенизируется, общественно-политические отношения сводятся к взаимодействию двух вневременных субъектов: русских и нерусских, что позволяет формулировать задачу вернуть себе «настоящую русскую культуру Белых Людей» (Крылов 2016).

В идеологии рассматриваемого круга националистов история России трактуется в связи с традициями Российской империи, которая отождествляется с властью народа. Соответствующий исторический контент является 
одним из основных на сайте «Спутника и погрома». Падение империи рассматривается как поражение русской нации, приведшее к становлению власти меньшинств. Кем бы ни был русский националист - монархистом или республиканцем - революция 1917 г. является ключевой точкой отсчета, а апелляция к ней - важнейшим элементом националистического дискурса.

В то же время демонизация Октября не исключает возможности конструктивного использования наследия СССР. В самом названии ресурса «Спутник и погром» спутник трактуется как «триумф разума». Для присвоения советского прошлого достаточно подчеркнуть, что достижение русских в СССР совершались вопреки советским порядкам (Спутник и Погром 2014a). Тема внутренних врагов в интерпретации событий столетней давности стала проявляться в дискурсе власти после 2011 г. (Малинова 2015: 79). В выступлениях Путина 2012 и 2014 гг. большевики упоминались как «национальные предатели». Причем в вступлении на молодежном форуме «Селигер-2014» были проведены параллели с деятелями политической оппозиции (Меликян 2016).

\section{«Научный национализм»}

Вторая риторическая линия (теоретическая) выражается в атаке на современные официальные формулировки единства российской нации. Формирование образа внутреннего врага русским национализмом во многом является реакцией на поликультурную идеологию современной России. Речь идет о ключевых документах, определяющих государственную национальную политику - Конституцию и Концепцию государственной национальной политики, которая была обновлена в 2012 г. В конституции закреплено определение «многонациональный народ России», которое, вместе с формулировкой «россиянин», стало нарицательным и активно атакуется националистами. В качестве синонима при этом используются определения «советский», «новиоп», «многонационал», «космополит». В самой формулировке Галковский видит противоречие - обозначение «мы» деперсонифицируется множествами «разнородным народом» и «соединенными общей судьбой». Отсюда делается вывод, что речь идет о «многонациональной», то есть «разнородной», «разночинно-инородной» «кодле»: «По этой конституции у русских отняли родину, право на национальный очаг и национальную культуру, превратили в париев их и их потомков» (Галковский 2006b).

Эту же мысль развивает Павел Святенков на страницах журнала «Вопросы национализма» в работе под говорящим названием «Все против русских» (Святенков 2012). Другой автор также делает категорический вывод:

«Закон один для всех» возможен ТОЛЬКО в национальном государстве. У русских его нет, а есть многонационалочка, состоящая из народовхозяйчиков, терроризирующих бесправных русских (Крылов 2015). 
Аналогичным нападкам подвергается и «Стратегия государственной национальной политики». С точки зрения Севастьянова, главная ее проблема заключается в нежелании авторов замечать противоречие между концептом «российской нации» и федеративным устройством России, где существуют национальные республики, округа и иные национально-территориальные образования: «О какой "российской нации" может идти речь, если у татар, башкир, чеченцев, евреев, якутов, адыгов и т.д. есть свои национальнотерриториальные образования, свой суверенитет?» (Севастьянов 2012b). В коротком манифесте «Почему я русский националист», появившемся на сайте «Спутник и Погром» в ноябре 2016 г. Просвирнин обозначает внутреннего врага 20 раз, чаще всего - 14 раз - употребляя термин «многонационал» (Просвирнин 2016). Консолидированное отношение современных русских националистов к «российскости» еще раз ярко проявилось в их реакции на заявления о необходимости создания закона о российской нации. На одобренную Путиным инициативу откликнулись многие публицисты правого толка, в частности Дмитрий Ольшанский: «Не надо верить в "россиян"». Россия - это именно «русские и союзные им общины меньшинств», а вовсе не "россияне РФ"» (Ольшанский 2017).

Нападкам со стороны русских националистов регулярно подвергается известный антрополог Валерий Тишков, который стоял у истоков государственной политики, ориентированной на формирование гражданской российской нации. Особенно популярны атаки на методологию социального конструктивизма, которую академик последовательно отстаивает: «...а потом придут тишковцы и скажут, что русских никаких нет, потому что Тишков нацию отменил» (Крылов 2010b). В связи с этим важно отметить, что идеи националистов все чаще облекаются в академические формы. Подобные процессы характерны не только для России, термин «научный национализм» (scientific nationalism) получил второе рождение в целом ряде работ, касающихся феномена появления харизматичных националистов-интеллектуалов, оперирующих околонаучной терминологией и таким образом пытающихся вести дискуссию респектабельным языком (Maly 2013).

\section{Этнонационализм}

Наконец, третья, наиболее агрессивная риторическая линия в формировании образа внутреннего врага обращена на дискредитацию конкретных этнических сообществ. В отношении мигрантов агрессивная риторика современного русского национализма достигает своего апофеоза (Laruelle 2009). Атмосфера ужаса формируется с помощью сознательного преувеличения масштабов миграции, что позволяет представлять русских как меньшинство. Именно перспектива «поглощения азиатами», с точки зрения современного русского национализма, основная опасность для русской нации. По их мнению, это тот враг, который непосредственно, 
лицом к лицу, противостоит русской нации, при этом является ее полным культурным антиподом и главной угрозой.

В содержательных характеристиках внутреннего врага русского народа националисты отводят центральное место представителям Кавказа. Можно сказать, что в идеологии современного национализма место, которое в построениях неоповченников занимали евреи, постепенно заняли кавказцы. При этом трактуются они в расовом контексте, поскольку различий между населением российских республик и государств Закавказья чаще всего не проводится. Это находит отражение в общественном настроении россиян, в котором отмечается снижение антисемитизма на фоне распространения новых врагов (Laruelle 2009). Именно кавказцы являются главными представителями колониальной администрации Великобритании. Крылов, в частности, дает такую характеристику чеченцев: «устроены как кентавр: дикое мохнатое тело, к которому пришита английская голова» (Крылов 2013). Похожими качествами наделяет Галковский грузин: «грузинам в России надо действительно помочь. Прежде всего, привести разбалованную, но отработавшую свое английскую касту азиатов в чувство» (Галковский 2006а).

Размышляя о двуличной стратегии Лондона, Крылов обращается к вопросу о выдаче обвиняемого в России во многих тяжких преступлениях Ахмада Закаева. В качестве аргумента Крылов приводит короткий «разоблачающий» исторический сюжет:

...если снова обратиться к истории, то можно узнать много интересного о англо-чеченских связях, уходящих в века. Например, о том, что среди чеченцев крайне популярна Британия. О некоем предсказании, согласно которому чеченцы когда-нибудь будут спасены Англией (Крылов 2005).

Антикавказский дискурс раскрывается не только в терминах предательства и коллаборационизма. Отношение с кавказскими народами для националистов приобретает экзистенциальный масштаб, поскольку, как отмечает еще один автор «Вопросов национализма» Олег Неменский под вопрос ставится существование самой русской бытовой культуры. Уголовные преступления кавказцев, которые обсуждает Неменский, носят по преимуществу бытовой характер. Однако противопоставление бытовых и национальных преступлений, с его точки зрения, не обосновано, поскольку «быт - уникальное русское понятие. Заметьте, оно не переводится на другие языки - только через выражения, причём их смысл не вполне адекватен нашему слову» (Неменский 2011: 12). Отсюда абсолютизация:

И это страх перед таким явлением, как «бытовой национализм»-тоже совсем не переводимое, оригинальное наше понятие, обозначающее агрессивное введение этнических различений в бытовую социальную реальность (там же). 
Риторика антикавказских построений современного национализма агрессивной лексикой и выраженным ориентализмом близка к мигрантофобской. Однако в концепции врага трудовые иммигранты из Средней Азии выполняют отличную от «кавказцев» функцию. Изменения этнического состава российских городов в результате миграции граждан Средней Азии националисты рассматривают как непосредственное проявление процесса целенаправленной «азиатизации» России. Яркий пример - сочинение Холмогорова с характерным названием «Предчувствие Орды». Автор утверждает: «Столица России сегодня превратилась в нерусский город. Без пяти минут это "новый Сарай"» (Холмогоров 2011). Если «кавказцы», как и другие «национальные меньшинства», являются представителями колониальной администрации, обеспечивающими господство Запада над Россией, то мигранты - инструментом, который используется для проведения политики ассимиляции русского народа.

\section{Заключение}

Правый (горизонтальный) популизм апеллирует к основам социальной идентификации, проводя границу между теми, кто «разделяет наш образ жизни», и теми, кто «угрожает нашему образу жизни» (Brubaker 2017). Включение идеологии национализма в официальную риторику приводит к упрощению социальной повестки, которая смещается от политического вопроса «какие мы?» к экзистенциальному вопросу «кто мы?». Ответ на него подразумевает выведение за пределы политической жизни целые сообщества, которым приписывается статус «внутренних врагов».

Современным идеологам русского национализма приходится решать сложную задачу формирования целостного образа нации в условиях стремительных социальных и технических трансформаций. Для того чтобы вместить все разнообразие современного националистического дискурса с его противоречиями в общую доктрину, идеологи русского национализма вынуждены постоянно реинтерпретировать накопленные фобии. Современный русский национализм отвечает этому вызову, расширяя тематику исторических нарративов, при этом он задействует конспирологические построения и использует академическую стилистику.

Государственная риторика принимает концепты русских националистов избирательно и ситуативно. Исторический нарратив националистов близок к официозному, он может отличаться не содержательно, а эстетически. Как следствие, вовлечение идеологем националистов в официальный контекст не проходит без их трансформации. Наиболее остро раскрылись противоречия между националистами этническими и имперскими (Horvath 2015). По мнению ряда исследователей, в контексте украинских событий 2014-2015 гг. власть сделала выбор в пользу имперского варианта, отвергнув строительство национального государства 
(Понарин, Комин 2016: 89), что привело к упадку движения националдемократов (Pain 2016: 56-57).

С приближением президентских кампаний интерес к националистической риторике со стороны власти ослабевает. Остались в ностальгических воспоминаниях «межуевские известия», «Спутник и Погром» блокируется Роскомнадзором, а националист Дмитрий Демушкин осужден по уголовному делу об экстремизме. Однако, если исключение из публичного пространства националистических интеллектуалов задача скорее техническая, то развеять националистические сентенции общества, очевидно, сложнее. Радикальная деполитизация, или, в определении Славоя Жижека - ультраполитика, потому и используется, что перекрыть повестку секъюритизации невозможно (Žižek 1998). С одной стороны, такая стратегия подразумевает постоянный контроль над общественным сознанием, что требует значительных материальных и инфраструктурных ресурсов, с другой, когда патриотический отклик в общественной жизни остается ведущим мотивом, невозможно формирование позитивной социальной повестки.

\section{Список источников}

Галковский Д.Е. (1994) Русская политика и русская философия. Иное. Доступно по ссылке: http://old.russ.ru/antolog/inoe/galkov.htm (дата обращения: 22 марта 2018).

Галковский Д.Е. (2006а) О грузинах объективно: шуты. Доступно по ссылке: http:// galkovsky.livejournal.com/79106.html (дата обращения: 22 марта 2018).

Галковский Д.Е. (2006b) Голье в Африке или зайцы во хмелю. Доступно по ссылке: https:/galkovsky.livejournal.com/76412.html (дата обращения: 22 марта 2018).

Галковский Д. Е. (2009) Два идиота. М.: Издательство Дмитрия Галковского.

Галковский Д.Е. (2012) Новиопы. Доступно по ссылке: http:/galkovsky.livejournal. com/199706.html (дата обращения: 22 марта 2018).

Жучковский А. (2012) Благодарственное письмо к кавказцам. Спутник и Погром. Доступно по ссылке: http://sputnikipogrom.com/2012/articles/103.php (дата обращения: 22. марта 2018).

Крылов К. (2005) Слушай, Британия. Спецназ России, 7 (106). Доступно по ссылке: http://www.specnaz.ru/article/?735 (дата обращения: 22 марта 2018).

Крылов К. (2010а) Запись в блоге от 20.09.2010. Доступно по ссылке: https://new. spring.me/\#!/krylov/q/1154635226 (дата обращения: 22 марта 2018).

Крылов К. (2010b) Запись в блоге от 14.11.2010. Доступно по ссылке: http://krylov. cc/blog/2010/11/14/8258 (дата обращения: 22 марта 2018).

Крылов К. (2010с) От редактора. Вопросы начионализма. Доступно по ссылке: http://vnatio.org/section3 (дата обращения: 22 марта 2018).

Крылов К. (2013) Запись в блоге от 08.08.2013. Доступно по ссылке: http://krylov.cc/ prnt.php?id=13610 (дата обращения: 22 марта 2018). 
Крылов К. (2015) Запись в блоге от 16.05.2015. Доступно по ссылке http://krylov.cc/ blog/2015/05/16/13471\#li-comment-751561 (дата обращения: 22 марта 2018).

Крылов К. (2016) 3anuсь в Facebook om 29.02.2016. Доступно по ссылке: https://www. facebook.com/k.a.krylov/posts/1004374179628973 (дата обращения: 22 марта 2018).

Крылов К. (2017) 3anuсь в Facebook om 23.10.2017. Доступно по ссылке: https://www. facebook.com/k.a.krylov/posts/1543091945757191 (дата обращения: 28 марта 2018).

Малинова О. (2015) Актуальное прошлое: Символическая политика властвующей элиты и дилеммы российской идентичности. М.: Политическая энциклопедия.

Меликян Т. (2016) Заложили атомную бомбу. Лента.py. Доступно по ссылке: https:/ lenta.ru/articles/2016/01/24/putin_lenin/ (дата обращения: 28 марта 2018).

Митрохин Н. (2003) Русская партия: Движение русских националистов в СССР. 1953-1985 годbl. М.: Новое литературное обозрение.

Национально-демократическая партия (2012) Программа Всероссийской политической партии «Национально-Демократическая партия». Доступно по ссылке: http:/ www.rosndp.org/Home/Program (дата обращения: 28 марта 2018).

Неменский О. (2011) Провал гипнотизера. Вопросы национализма, (5): 8-13.

Ольшанский Д. (2017) Запись в Facebook om 10.02.2017. Доступно по ссылке: https:// www.facebook.com/spandaryan/posts/1320531414634340 (дата обращения: 22 марта 2017).

Партэ К. (2004) Русская деревенская проза: светлое прошлое. Томск: Издательство Томского университета.

Понарин Э. Д., Комин М. О. (2016). Дилемма русского национализма («Имперский» и этнический национализм в постсоветской России). Полития, (4): 89.

Просвирнин Е. (2016) Почему я - русский националист? Спутник и Погром. Доступно по ссылке: https:/sputnikipogrom.com/mustread/61931/a-russian-nationalist/\#. WNS2OPnyhhE (дата обращения: 22 марта 2017).

Самоваров А. (2013) Кто больший предатель - Ленин или генерал Власов? Агенство политических новостей. Доступ по ссылке: http://www.apn.ru/publications/article28554. htm (дата обращения: 22 марта 2018).

Святенков П. (2012) Все против русских. Доступно по ссылке: http://vnatio.org/arhivnomerov/node108/ (дата обращения: 22 марта 2017).

Севастьянов А. (2009) Почему все-таки не состоялась русская революция? Агенство политических новостей. Доступно по ссылке: http://www.apn.ru/special/article21844. htm (дата обращения: 22 марта 2017).

Севастьянов А. (2012а) Русские! Жить или умереть. Вопросы национализма, 10. Доступно по ссылке: http://vnatio.org/arhiv-nomerov/node16/ (дата обращения: 22 марта 2017).

Севастьянов А. (2012b) Стратегия государственной национальной политики - выход из тупика или новый тупик? Доступно по ссылке: http://www.apn.ru/publications/ article27705.htm (дата обращения: 22 марта 2017).

Сергеев С. (2012) Михаил Катков против Владимира Путина. Доступно по ссылке: http://vnatio.org/news2355/ (дата обращения: 22 марта 2017).

Спутник и Погром (2014а) Интервью главного редактора «Спутника и Погрома» проекту The Internet Times. Доступно по ссылке: https://sputnikipogrom.com/russia/22806/ the-internet-times (дата обращения: 22 марта 2017). 
Спутник и Погром (2014b) Запись в Twitter от 15.06.2014. Доступно по ссылке: https:/ twitter.com/sputnikipogrom/status/478195201992065024 (дата обращения: 22 марта 2018).

Спутник и Погром (2014c) Ценности «Спутника и Погрома». Доступно по ссылке: https:/sputnikipogrom.com/mustread/12442/ (дата обращения: 22 марта 2018).

Холмогоров Е. (2011) Предчувствие Орды. Русский обозреватель. Доступно по ссылке: http://www.rus-obr.ru/lj/14275 (дата обращения: 22 марта 2018).

Чернышов С. (1995) Иное. Путеводитель: Апология составителя. М.: СвР-Аргус.

Якушина О. (2012) Теория секьюритизации в международных отношениях. Доступно по ссылке: http://www.geopolitica.ru/article/teoriya-sekyuritizacii-v-mezhdunarodnyhotnosheniyah-chl (дата обращения: 22 марта 2017).

Brubaker R. (2017) Between Nationalism and Civilizationism: The European Populist Moment in Comparative Perspective. Ethnic and Racial Studies, 40 (8): 1191-1226.

Brubaker R., Cooper F. (2000) Beyond 'identity'. Theory and Society, (29): 1-47.

Colta.ru. (2013) Самый влиятельный интеллектуал России - 2013. Опрос в деталях. Доступ по ссылке: http://www.colta.ru/articles/specials/1658 (дата обращения: 22 марта 2018).

Gelman V. (2015) The Politics of Fear. How the Russian Regime Confronts Its Opponents. Russian Politics and Law, 53 (5-6): 10-21.

Horvath R. (2015) The Euromaidan and the Crisis of Russian Nationalism. Nationalities Papers, 43 (6): 819-839.

Kolstø P., Blakkisrud H. (eds.) (2016) The New Russian Nationalism: Imperialism, Ethnicity and Authoritarianism 2000-15. Edinburgh: Edinburgh University Press.

Laruelle M. (2009) In the Name of the Nation. London: Palgrave Macmillan.

Lipman M. (2015) The Kremlin Turns Ideological: Where This New Direction Could Lead. London: Palgrave Macmillan

Makarychev A., Yatsyk A. (2014) A New Russian Conservatism: Domestic Roots and Repercussions for Europe. Notes Internacionals, (93): 143-160.

Maly N. (2013) 'Scientific' Nationalism: N-VA, Banal Nationalism and the Battle for the Flemish Nation. Tiburg: Tiburg University Press.

Pain E. (2016) The Imperial Syndrome and its Influence on Russian Nationalism. The New Russian Nationalism. Edinburgh: Edinburgh University Press: 46-74.

Shnirelman V. A., Komarova G. A. (1997) Majority as a Minority: The Russian Ethno-Nationalism and its Ideology in the 1970s-1990s. H.-R. Wicker (ed.) Rethinking Nationalism and Ethnicity: The Struggle for Meaning and Order in Europe. Oxford: Berg:211-224.

Žižek S. (1998) A Leftist Plea for 'Eurocentrism'. Critical Inquiry, 24 (4): 988-1009. 


\section{THE 'INTERNAL ENEMIES' OF CONTEMPORARY RUSSIAN NATIONALISM}

The third presidential term of Vladimir Putin is characterized by the active inclusion of a national security agenda in the social policy context. In this regard, it appears some ideologems from contemporary Russian nationalist movements are being incorporated into mainstream state discourses. One of the best examples of this is the theme of 'internal enemies'. This article unpacks some of the key features behind the formation of 'internal enemies'. The term 'Russian nationalists' can be problematic as a category of analysis due to the fragmented and diffuse movements potentially contained under this heading. To avoid this issue the term is used in this article as a category of political practice. Of particular interest here are those public figures who call themselves Russian nationalists. In this intellectual space, there are three rhetorical strategies that shape the image of the 'internal enemy': historical, theoretical and ethnic. The first is reduced to the idea that the national minorities have played a key role in the destruction of the Russian Empire. The second rhetorical line attacks the official formulations of Russian state nationality policy, something that can be understood as a reaction against the multicultural ideology of contemporary Russia. Finally, the third and most aggressive rhetorical line targets specific ethnic communities. The central place in characteristics of the internal enemy in this sense is given to representatives of the North Caucasus.

Keywords: Contemporary Russian nationalism, scientific nationalism, Galkovsky, novyop, internal enemy

DOI: 10.17323/727-0634-2018-16-2-279-294

\section{References}

Brubaker R. (2017) Between Nationalism and Civilizationism: The European Populist Moment in Comparative Perspective, Ethnic and Racial Studies, 40 (8): 1191-1226.

Brubaker R., Cooper F. (2000) Beyond 'Identity'. Theory and Society, (29): 1-47

Chernyshov S. (1995) Inoe. putevoditel' apologiya sostavitelya. [The Other. A Guide. An Apology of the Creator]. Moscow: SvR-Argus.

Ivan Vladimirovich Bobrov $-4^{\text {th }}$ year student of Siberian Institute of the Russian Presidential Academy of National Economy and Public Administration, Novosibirsk, Russian Federation. Email: ivan.v.bobrov@gmail.com

Mikhailov Dmitrii Alekseevich - (PhD), Associate Professor of Siberian Institute at the Russian Presidential Academy of National Economy and Public Administration, Novosibirsk, Russian Federation. Email: damihan@yandex.ru 
Colta.ru. (2013) Samyy vliyatel'nyy intellektual Rossii-2013. Opros v detalyakh [The Most Influential Intellectuals of Russia in 2013. Focus on the Survey]. Available at: http://www. colta.ru/articles/specials/1658 (accessed 22 March 2018).

Galkovskiy D.E. (1994) Russkaya politika i russkaya filosofiya [Russian Politics and Russian Philosophy]. Inoe [Otherwise]. Available at: http://old.russ.ru/antolog/inoe/galkov.htm (accessed 22 March 2018).

Galkovskiy D.E. (2006a) O gruzinakh ob"ektivno: shuty [Objectively about Georgians: The Jokers]. Available at: http://galkovsky.livejournal.com/79106.html (accessed 22 March 2018).

Galkovskiy D.E. (2006b) Golye v Afrike ili zaytsy vo khmelyu [Naked in Africa or Drunk Hares]. Available at: https:/galkovsky.livejournal.com/76412.html (accessed 22 March 2018).

Galkovskiy D.E. (2009) Dva idiota [Two Idiots]. Moscow: Izdatel'stvo Dmitriya Galkovskogo.

Galkovskiy D.E. (2012) Noviopy [Noviops]. Available at: http:/galkovsky.livejournal.com/ 199706.html (accessed 22 March 2018).

Gelman V. (2015) The Politics of Fear. How the Russian Regime Confronts Its Opponents. Russian Politics and Law, 53 (5-6): 10-21.

Horvath R. (2015) The Euromaidan and the Crisis of Russian Nationalism. Nationalities Papers, 43 (6): 819-839.

Kholmogorov E. (2011) Predchuvstvie Ordy [Anticipation of the Horde]. Russkiy obozrevatel' [Russian Observer]. Available at: http://www.rus-obr.ru/lj/14275 (accessed 22 March 2018).

Kolstø P., Blakkisrud H. (eds.) (2016) The New Russian Nationalism: Imperialism, Ethnicity and Authoritarianism 2000-15. Edinburgh: Edinburgh University Press.

Krylov K. (2005) Slushay, Britaniya [Britain, Listen]. Spetsnaz Rossii, 7 (106). Available at: http://www.specnaz.ru/article/?735 (accessed 22 March 2018).

Krylov K. (2010a) Blog Post at 20.09.2010. Available at: https://new.spring.me/\#!/krylov/ q/1154635226 (accessed 22 March 2018).

Krylov K. (2010b) Blog Post at 14.11.2010. Available at: http://krylov.cc/blog/2010/11/14/8258 (accessed 22 March 2018).

Krylov K. (2010c) From the editor. Voprosy natsionalizma [Issues of Nationalism]. Available at: http://vnatio.org/section3 (accessed 22 March 2018).

Krylov K. (2013) Blog Post at 08.08.2013. Available at: http://krylov.cc/prnt.php?id=13610 (accessed 22 March 2018).

Krylov K. (2015) Blog Post at 16.05.2015. Available at: http://krylov.cc/blog/2015/05/16/ 13471\#1i-comment-751561 (accessed 22 March 2018).

Krylov K. (2016) Facebook Post at 29.02.2016. Available at: https://www.facebook.com/ k.a.krylov/posts/1004374179628973 (accessed 22 March 2018).

Krylov K. (2017) Facebook Post at 23.10.2017. Available at: https://www.facebook.com/ k.a.krylov/posts/1543091945757191 (accessed 22 March 2018).

Laruelle M. (2009) In the Name of the Nation. London: Palgrave Macmillan. 
Lipman M. (2015) The Kremlin Turns Ideological: Where This New Direction Could Lead. London: Palgrave Macmillan.

Makarychev A., Yatsyk A. (2014) A New Russian Conservatism: Domestic Roots and Repercussions for Europe. Notes Internacionals, (93): 143-160.

Malinova O. (2015) Aktual'noe proshloe: Simvolicheskaya politika vlastvuyushchey elity $i$ dilemmy rossiyskoy identichnosti [Current Past: Symbolic Politics of the Ruling Elite and Dilemmas of Russian Identity]. Moscow: Politicheskaya entsiklopediya.

Maly N. (2013) 'Scientific' Nationalism: N-VA, Banal Nationalism and the Battle for the Flemish Nation. Tiburg: Tiburg University Press.

Melikyan T. (2016) Zalozhili atomnuyu bombu [A Nuclear Bomb was Planted]. Lenta.ru. Available at: https://lenta.ru/articles/2016/01/24/putin_lenin/ (accessed 22 March 2018).

Mitrokhin N. (2003) Russkaya partiya: Dvizhenie russkikh natsionalistov v SSSR. 1953-1985 gody [The Russian Party: The Russian Nationalist Movement in the USSR. 1953-1985]. Moscow: Novoe literaturnoe obozrenie

Natsional'no-demokraticheskaya partiya (2012) Programma vserossiyskoy politicheskoy partii 'natsional'no-demokraticheskaya partiya' [National Democratic Party Program]. Available at: http://www.rosndp.org/Home/Program (accessed 22 March 2018).

Nemenskiy O. (2011) Proval gipnotizera [The Failure of the Hypnotist]. Voprosy natsionalizma [Issues of Nationalism], (5): 8-13.

Ol'shanskiy D. (2017) Facebook Post at 10.02.2017. Available at: https://www.facebook. com/spandaryan/posts/1320531414634340 (accessed 22 March 2018).

Pain E. (2016) The Imperial Syndrome and its Influence on Russian Nationalism. P. Kolstø., H. Blakkisrud (eds.) The New Russian Nationalism. Edinburgh: Edinburgh University Press: 46-74.

Parte K. (2004) Russkaya derevenskaya proza: svetloe proshloe [Russian Village Prose: The Good Old Days]. Tomsk: Izdatel'stvo Tomskogo universiteta.

Ponarin E., Komin M. (2016) Dilemma russkogo natsionalizma [The Dilemma of the Russian Nationalism]. Politia, (4): 89.

Prosvirnin E. (2016) Pochemu ya - russkiy natsionalist? [Why I am a Russian Nationalist?]. Sputnik i Pogrom. Available at: https://sputnikipogrom.com/mustread/61931/a-russiannationalist/\#.WNS2OPnyhhE (accessed 22 March 2018).

Samovarov A. (2013) Kto bol'shiy predatel' - Lenin ili general Vlasov? [Who is the Biggest Traitor: Lenin or General Vlasov?]. Agenstvo politicheskikh novostey [Political News Agency]. Available at: http://www.apn.ru/publications/article28554.htm (accessed 22 March 2018).

Shnirelman V. A., Komarova G. A. (1997) Majority as a Minority: The Russian Ethno-Nationalism and its Ideology in the 1970s-1990s. In: H. R. Wicker (ed.) Rethinking Nationalism and Ethnicity: The Struggle for Meaning and Order in Europe. Oxford: Berg:211-224.

Sevast'yanov A. (2009) Pochemu vse-taki ne sostoyalas' russkaya revolyutsiya? [Why the Russian national Revolution didn't Happen?]. Agenstvo politicheskikh novostey [Political News Agency]. Available at: http://www.apn.ru/special/article21844.htm (accessed 22 March 2018). 
Sevast'yanov A. (2012a) Russkie! Zhit' ili umeret' [Russians! To Live or to Die]. Voprosy Natsionalizma [Issues of Nationalism], (10). Available at: http://vnatio.org/arhiv-nomerov/ node16/ (accessed 22 March 2017).

Sevast'yanov A. (2012b) Strategiya gosudarstvennoy natsional'noy politiki - vykhod iz tupika ili novyy tupik? [The Strategy of State National Policy - a Way Out of the Impasse or a New Topic?]. Available at: http://www.apn.ru/publications/article27705.htm (accessed 22 March 2017).

Sergeev S. (2012) Mikhail Katkov protiv Vladimira Putina [Michail Katkov versus Vladimir Putin]. Available at: http://vnatio.org/news2355/ (accessed 22 March 2017).

Sputnik i Pogrom (2014a) Interv'yu glavnogo redaktora 'Sputnika i Pogroma' proektu The Internet Times [Interview of 'Sputnik i pogroma' editor-in-chief to Internet Times]. Available at: https://sputnikipogrom.com/russia/22806/the-internet-times (accessed 22 March 2018).

Sputnik i Pogrom (2014b) Twitter Post at 15.06.2014. Available at: https://twitter.com/sputnikipogrom/status/478195201992065024 (accessed 22 March 2018).

Sputnik i Pogrom (2014c) Tsennosti 'Sputnika i Pogroma' [Values of 'Sputnik i Pogrom']. Available at https://sputnikipogrom.com/mustread/12442 (accessed 22 March 2018).

Svyatenkov P. (2012) Vse protiv russkikh [Everything Against Russians]. Available at http:// vnatio.org/arhiv-nomerov/node108/ (accessed 22 March 2018).

Yakushina O. (2012) Teorija sek' juritizacii v mezhdunarodnyh otnoshenijah [Securitization Theory in the International Relations]. Available at: http://www.geopolitica.ru/article/ teoriya-sekyuritizacii-v-mezhdunarodnyh-otnosheniyah-ch1 (accessed 22 March 2018).

Zhuchkovskiy A. (2012) Blagodarstvennoe pis'mo k kavkaztsam [The Letter of Gratitude to Caucasians]. Sputnik i Pogrom. Available at: http://sputnikipogrom.com/2012/articles/103. php (accessed 22 March 2018).

Žižek S. (1998) A Leftist Plea for 'Eurocentrism'. Critical Inquiry, 24 (4): 988-1009. 